The Geographical Journal of Nepal, Vol. 7, 2009: 15-22

\title{
Farmer's Choice and Farmer's Voice on the Use of Local versus Modern Inputs in Peri-Urban Agriculture in Kathmandu Valley, Nepal
}

\author{
Kanhaiya Sapkota \\ Associate Professor \\ Central Department of Geography, Tribhuvan University \\ kanhaiya.sapkota@gmail.com
}

\begin{abstract}
Farmers' knowledge and practices on local versus modern inputs on peri-urban agriculture were investigated by interviewing 20 vegetable growers with purposive sampling in the Manahara river basin of Kathmandu Valley between November 2005 and January 2006. Further data were collected from group discussions, key informant survey, and observation. This paper attempts to explore some contradictions between scientific and local knowledge on peri-urban agriculture practices. The farmers have now intensified their production to meet the urban demand. The transition has made the farmers adopting improved farming techniques related to the green revolution over traditional practices. The farmers' practices demonstrate to some extent a link between scientific and indigenous knowledge. They also realise that the institutional extension support is essential to identify and proper use of agricultural inputs available at the local markets, so that the agriculture production can be achieved in a balanced way.
\end{abstract}

\section{Background}

An urban area tends to sprawl over its vicinity. The urbanization process accelerates when there is a high rate of population growth and high urban-bound migration, which results into high rate of demand for land for various non-agricultural uses like housing, institutions, hotels, shopping complexes, recreational and sports, parks, industries, etc. The high rate of demand for urban land brings about high 'opportunity costs' of urban agricultural land. Consequently, land that is classified as agricultural land in such rapidly growing urban areas will be reduced continually and traditional agricultural systems will be changed. Ultimately, agriculture in urban areas may be found only on lands that have been planned but not yet been used for nonagricultural purposes.

It is no doubt that the people living in urban and peri-urban areas are engaged in some sort of agricultural activities - crop production, vegetable farming (horticulture), floriculture, or livestock raising - on small fields, backyards, river banks, and even rooftops. Urban agriculture can be defined as the growing of plants and raising of livestock for food and related activities like production and distribution of inputs, and processing and marketing of products within the 
city or in the peri-urban areas (Pradhan 2008). It is a natural phenomenon that such activities are carried out wherever possible and necessitated. Peri-urban agriculture (PUA) is by nature supplementary to rural agriculture and plays only a marginal role in the development of national economy and security (Briggs, Badir, and Mekki 1999). Farmland prices may rise as urbanization intensifies but farmers can either shift to intensive farming or reap windfall profits by selling land for urban uses.

PUA contributes better livelihood of the urban poor by providing non-market access to food and offering jobs and incomes (ECOSOC 2000). It refers to farming nearby the cities, generally intensive or semi or fully commercial production which is becoming a permanent pattern of urban land use. Growing urban population and their demands for food and other agricultural products will also have some major impacts on land uses in peri-urban areas. Therefore the importance of PUA in this regard is crucial especially in low-income developing countries like Nepal. It is also often a main source of supply for fresh products such as vegetables, fruits and fresh milk. Food security and health of urban families partly hinge on PUA. These positive aspects of PUA have only recently been recognized and drawn attention of international community (Sapkota and Andersen 2004).

PUA has been practiced from the very beginning in Nepal and the farmers have been operating agriculture under different sets of conditions and choices. However, PUA has a huge challenge to protect it from rapid and haphazard urbanisation of Kathmandu, mainly due to rapid rate of migration with over 5.5 per cent per annum (Pradhan 2004). Some studies have been carried out to analyse the urban agriculture in Kathmandu valley (Pradhan 2008; Devkota and Pradhan 2006; Rajbanshi 2009). In Kathmandu, production of agriculture crops under PUA is usually for the self consumption, yet not all products are consumed. For these, farmers who sell all or part of their produce, market access is an important factor and most of the agricultural products are determined by urban demands. Further, because of proximity to the means of transports and communication, labour availability and market, agriculture in the peri-urban areas is becoming modernised rapidly. It is in this context, the aim of this paper is sought to explore some contradiction and interface between scientific and local knowledge on peri-urban agriculture in the Manahara river basin of Kathmandu valley, Nepal.

\section{Study Site, Methods and Materials}

The Manahara river basin or low-lying land (Phant) belonged administratively to Madhyapurthimi municipality lies in the central part of Kathmandu valley. It is selected for this study for many reasons: firstly, this area is being intensively used for agriculture due to favourable soils and drainage for the production of all-seasons crops; secondly, the traditional irrigation system is still maintained which is not sufficient for rice production, the major staple crop; thirdly, this area lies nearby to major market demand centres such as Kathmandu and Patan; and lastly, the local farmers have easy access to major city road networks that have been essentially important for bringing farm requirements like agricultural tools, fertilizers, pesticides, as well as for transporting their perishable vegetable products to the demand places. Thus, this area is one of the main sources of production of varieties of seasonal vegetables for the urban dwellers of Kathmandu Valley.

Data were acquired from the field work carried out during 2005-2006. A preliminary survey was undertaken using a checklist for gaining information about the best general locations of preferred 
cultivation sites and then an in-depth interview and observation methods were used for the data collection. The survey tools like structured questionnaires and observation protocol sheets were used respectively in both survey methods. In the in-depth interview, altogether twenty farmers who were also the heads of the households were participated. To gain a better appreciation of the epistemologies and practice of peri-urban farming, the researcher conducted detailed interviews (question focused) with the local farmers. Interviews with the key informants (ward chairman, senior citizens, and agrovet shopkeepers) were undertaken to gain an overview of their perceptions about how the PUA system was being managed. Further information was obtained from several informal discussions being made with other local informants.

The local people's ideas regarding the fertility of soil, use of manure and fertilizers and other inputs, micronutrients, etc were recorded and analysed so as to find out to what extent they correlated with the expert knowledge. The analysis is basically of descriptive nature. This is so for bringing out the farmer's knowledge and closeness to the scientific knowledge.

\section{Results and Discussions}

\section{Soil Fertility Status and farmers' knowledge}

In the Manahara basin, there exist two basic types of soil fertility maintenance such as manuring and management. The practices of the farmers are that crop residues are burned, ash added to the farmland, chicken and livestock manure spread on the farm fields, and leaf litter and night soil (in some cases) also spread on the fields. These are widely practiced by the local farmers in both Khet (irrigated land) and Bari (un-irrigated upland terraces). The knowledge of the farmers is that they use farmyard manure (FYM) or almost all vegetable plants on the farmlands. FYM is a mixture of straw, cow dung, urine and other plant materials. According to them, raw cow dung is not good for vegetable farming and therefore, they prefer FYM for the farmland, because they know that FYM regulates the supply of nitrogen and changes the colour of the soil which is essential for absorbing sunlight. To some extent, the farmers burn grasses before raining in order to enhance fertility levels through the release of nutrients.

The analysis of soil samples indicates that the levels of nutrients are on the whole not a problem except boron. Most soil pH values fall within 3.5 to 5.4 (extremely acidic to moderately acidic), indicating $\mathrm{pH}$ to be more serious than reported from other middle hill areas, such as Jhiku Khola area in the east, where the $\mathrm{pH}$ value was 4.94 in red soil and 4.78 in non-red soils (Schreier et.al 1994 cited in Shah 1996). There was a large variation in available P levels, ranging high to very high. About fifty five per cent of exchangeable $\mathrm{K}$ values were in the range of high to very high. Boron is completely deficit and in the case of $\mathrm{Zn}$ it is not much problem.

Most farmers have practiced intensive vegetable farming that allowed them to produce more vegetables and managed plant diseases for some decades with few outside inputs. Traditional farming systems and managements still exist in the area, to some extent. The traditional system is being passed down for many generations. However, many of their successful practices have been forgotten or abandoned in some cases of peri-urban farmers.

About 25 years ago, most of the local farmers used to use night soils for the betterment of soil and thus so as nutrients for the plants. They believed that the night soil was the main source of nutrients for the vegetables. But now, this practice is almost disappeared because of the 
availability of different industrial product nutrients (i.e. chemical fertilizers and micronutrients). According to them, when they used only FYM, organic manure, and homemade pesticides and insecticides, the quality of soil was very good and in fertile condition. But when they began to use chemical fertilizers without adequate knowledge in their vegetable farms, they complained that the quality of land has been degraded and faced the plant-damaging problems. They still prefer to apply organic manure in the field, instead of using high cost and low quality chemical fertilizers and other nutrients.

Table 1: Troubleshooting chart for compost pile/heap

\begin{tabular}{|c|c|c|}
\hline $\begin{array}{l}\text { Farmer's claim regarding } \\
\text { compost preparation }\end{array}$ & $\begin{array}{l}\text { Problem of the symptoms } \\
\text { which farmer's claim }\end{array}$ & $\begin{array}{l}\text { Suggestions from Agricultural } \\
\text { Extension Office }\end{array}$ \\
\hline $\begin{array}{l}\text { - The pile is damp and good } \\
\text { smelling, but still not heat } \\
\text { up }\end{array}$ & - Lack of nitrogen & $\begin{array}{l}\text { - Mix in a nitrogen source } \\
\text { such as manure }\end{array}$ \\
\hline $\begin{array}{l}\text { - The compost pile is cold } \\
\text { and wet }\end{array}$ & $\begin{array}{l}\text { Too much rain or } \\
\text { moisture }\end{array}$ & $\begin{array}{l}\text { - Cover with a mulch of } \\
\text { finished compost or a tarp }\end{array}$ \\
\hline $\begin{array}{l}\text { - The compost is damp and } \\
\text { warm only in the middle }\end{array}$ & - Compost pile is too small & $\begin{array}{l}\text { - Collect more material and } \\
\text { mix it into the existing pile }\end{array}$ \\
\hline $\begin{array}{l}\text { - The pile attracts flies, } \\
\text { rodents, and pets, etc }\end{array}$ & $\begin{array}{l}\text { - Not mixed well. Meat } \\
\text { scraps may have been } \\
\text { added to the pile }\end{array}$ & $\begin{array}{l}\text { - Do not add meat scraps. } \\
\text { Mix the pile and cover with } \\
\text { soil }\end{array}$ \\
\hline $\begin{array}{l}\text { - The interior of the pile is } \\
\text { dry }\end{array}$ & - Not enough water & _ Moisten and turn pile \\
\hline _ Has a bad odour & - Not enough air & $\begin{array}{l}\text { - Aerate it. Add dry material } \\
\text { if the pile is too wet }\end{array}$ \\
\hline
\end{tabular}

Source: Field Survey 2005/06

Despite the preference of manure of the local farmers, it seems that they are facing the problems of compost preparation, which is basically embedded in their traditional practices or knowledge. Compost is not properly decomposed due to several reasons, as mentioned in Table 1. During the survey, the agricultural extension office provided suggestions about how to solve the problem of compost preparation. The farmers who had the problem of compost preparation, they did not consult nor visited to the extension officer, but instead they shared these problems with other farmers and tried to settle down the problem themselves. If they were not able to solve the problem they then consulted the agro-vets.

Thus, the farmers have practiced of a blending method of both local and scientific for soil fertility management. The farmers claimed that when chemical fertilizers and pesticides were introduced, the production of vegetables increased, but then gradually they faced a number of problems regarding the loss of soil quality. According to them, the soil turned into dry and harder and as a result, some of the vegetables they previously cultivated satisfactorily have not 
been grown as expected. It seems that the soil fertility has gradually been declined due to inadequate and imbalanced application of nutrients through chemical fertilizers and improper farming practices as to the demand of modern system. The dominant view expressed was that although the soils were of high quality, they now have become fragile for intensified cultivation due to frequent use of chemical fertilizers and pesticides. Thus, maintaining soil fertility has been a crucial challenge in having a sustainable agriculture in the Manahara basin (Sapkota 2003).

The farmers have also used crop rotation method. Different crops used and replenish different minerals. Some of the farmers used to leave crop residues on the field after harvesting for erosion prevention, retaining moisture and enriching the soil. For instance, the minerals within the maize stalks and hay as well as other plants decompose back into the soil and which in turn provide more organic matters to the soil. Farmers argued that even supply of chemical fertilizers is increasing, they are unable to maintain soil fertility, and yields are declining. It is argued that crop rotation is not always economically feasible particularly in the case of peri-urban agriculture system, because it is market oriented farming system and farmers depend on the urban demand.

According to Chaudhary and Manandhar (1996), Nepal's per hectare nutrient consumption is not only the lowest in Asia but also highly unbalanced in terms of NPK application. The cropping patterns have not incorporated legumes and other crops having nitrogen-fixing ability but were mostly based on market oriented crops, which possibly removed significant amounts of nutrients from the soil. The farmers have adopted improved variety of seeds and therefore they have given less attention to the traditional source of nutrients (organic manures from various sources like FYM, green manure, crop residues) for ecological maintenance of chemical and physical properties of the soil.

The fields are hoed one or two days before planting or sowing of seeds in the belief that it will exposure to the sun to kill the weeds. But in some cases, they left the weeds on the soil surface as protective mulch, to recycle nutrients and to allow nitrogen assimilation through the bacteria decomposing the plants. The crops can then develop fully. Similarly, they put some chicken manure with other compost manure during the field preparation or levelling the land for plantation. Manual weeding is carried out during the field preparation and in other times before harvesting. Burning weed is also a traditional practice. Here Rappaport's (1967) argument for the separate analyses of 'cognised' and 'operational' models is reflected, because we can categorise separate views on the basis of local and scientific knowledge. It indicates that the importance of the interaction from an 'outsider's perspective' which can help us to understand the relationship between the local knowledge and its correlation with the scientific explanations.

\section{Trend of Use of "Local" versus "Modern" Inputs}

Labour force is the main pillar particularly of the labour intensive farming system. Basically, the local farmers used to prefer to use their own family members as labours, but due to modernization, improvement in economic status, they now have limited family labour and have to hire labour mainly for the land preparation. After the introduction of chemical fertilizers and pesticides and insecticides in the farming, women's works have been reduced. Before that, the women used to prepare pesticides/insecticides by themselves at home and even put on the farm. Why the nature of women's work has now changed is that the insecticides/pesticides and even organic manure can be easily available in the market. 
A question was asked about the difference in the impact of use between two types of common chemical fertilizers such as urea and DAP (di-ammonium phosphate) during the time of sowing, the farmers responded that:

DAP turns out to be better because at the time of sowing, it gives the seed enough heat (Takat or Shakti) for the plant to grow and that it does till the end the plant maintains itself well. Urea cannot give so much. The heat given to the seeds through DAP will enable them to increase production later.

Similarly, they also told that "urea makes plant grow, DAP makes it sprout". To some extent, the local farmers have knowledge about the impact of the use of chemical fertilizers. Accordingly: "If we put more fertilizer, plant will grow taller. When it grows tall and we irrigate it, then there is a danger of the plant falling. If the standing paddy plant lodges, the production will be lower.

Decisions about what crops to grow in the field are directly tied with the availability of inputs. They claimed that excessive use of chemical fertilizers would adversely affect on the soil. In the interesting discourse of farmers, comparisons between manure (gobar mal) and chemical fertilizers (desi mal or rasaayanik mal or sarkari mal) loomed largely. While speaking of the strength of the soil, they inevitably pointed out a huge difference between manure and chemical fertilizer as well as among different kinds of fertilizers. The farmers were asked why they now needed larger amount of chemical fertilizers than in the past. They replied that due to the degradation of the quality of soils (dry), they now have used more and more chemical fertilizers than in the past. All the farmers thought that organic manure would be better for the land than the chemical fertilizers. According to them, manure releases its Takat or Shakti gradually, whereas chemical fertilizers release its energy all at once. They explained:

"There is an enormous quantity of power in gobar mal. Even urea does not have so much as gobar mal does have. Similarly, gobar mal allows to increasing the growing strength (Baliyo) of the land and makes the farmland soft and fertile. When the lands become fertile, the production will increase. If we apply gobar mal, its effects will last for several years. It doesn't dissolve all at once but the desi mal dissolves all at once."

These are some examples of knowledge of local farmers about soil fertility, use of manure and fertilizer and management. The farmers admitted that they have become lazy because of the easily available of fertilizers. There might be several reasons, such as lack of grazing land for livestock in the study area; rising in transportation cost day-by-day, not availability of manure in time of need through middlemen, etc. Whatever the reasons might be, they have to increasingly dependent on the use of chemical fertilizers and thus the use of chemical fertilizer has been increasing day by day. According to the farmers, applying chemical fertilizer in the rainy season is a tricky business:

When there is excess water, urea dissolves in it, goes underneath, and doesn't give its benefits to the crops. On the other hand, if we put it and there is no rain for four to six hours, it is all right. A minimum of six hours needed for the plant to absorb the nutrients. If it rains immediately after the application, it will go waste.

The farmers have used a wide range of micronutrient mixtures such as borax and boric acid; all referred to as 'vitamin' in the local terms to increase agricultural productivity. The local farmers 
believe that the use of micronutrients is necessary to put a stop to decrease in the productivity of soil caused by excessive use of chemical fertilizers in the past. But, they were not so much aware about the knowledge of the types of micronutrients required for the vegetable crops.

The farmers claimed that the quality of fertilizers and pesticides or insecticides available at the local markets was not good and that those importing from the neighbouring districts of India was not of good quality. As a result, they argued that the quality of soil decreased due to the use of those poor quality chemical inputs. To verify the quality, eight different types of chemical fertilizers were collected and analysed their properties in the laboratory. It was found that all those had an acceptable quality. Despite this, the local farmers did not believe in the Indian fertilizers; instead they trusted either on domestic products or those of Japanese, Indonesian, and Bangladeshi.

The above discussions indicate that soil fertility and nutrient use efficiency of the plants are very important matters to be considered for scientific plant nutrient management. Thus, proper knowledge of nutrient availability and nutrient use efficiency is essential for the local farmers in order to help increase in the vegetables production and mitigate the problem of environmental pollution due to overuse of fertilisers.

\section{Conclusion}

The peri-urban agriculture in the Kathmandu valley is facing a crucial challenge because of the rapid and haphazard urbanization. In recent years, the local young generations have no interest in their parental traditional farming activities, such as urban farming. They rather prefer other income generating activities. Although the peri-urban agriculture in the Manahara river basin is still gaining impressive achievements, the area is encroaching by the urban sprawls and that the existing production of vegetable crops has declined due to improper use of locally available substandard chemical fertilisers and diminishing in the use of traditionally practice manure.

Increase in the vegetable production is seen due to the use of chemical fertilizers. But the adverse impact of excessive use of chemical fertilizers and pesticides was also seen. Intensified cropping and used of fertilizers have led to very low $\mathrm{pH}$ values.

The local farmers have been trying for long time to sustain the agricultural production through using indigenous compost and farmyard manure system. This now has been replaced by the imported technologies of the green revolution such as chemical fertilizers, insecticides and pesticides and others. However, due to lack of adequate knowledge regarding fertilizers and other inputs, the local farmers have little or no idea about the contents and proper use of those inputs. They even have little knowledge about the nutrients demand by crops and nutrient supply from the soil. Yet, the urban agriculture in such peri-urban areas of Kathmandu valley is essential for income generation among the poor farmers, maintaining greenery, and meeting local demands of vegetables. Due to the lack of institutional extension support, the local farmers are not being able to produce the vegetable crops as desirable. Therefore, it is necessary to intervene for the scientific knowledge transfer to them not only for sustained production of agricultural system, but to enrich their power in the choice of inputs and crops for growing, as well. 


\section{References}

Boserup, E (1965), The Conditions of Agricultural Growth: The Economics of Agrarian Change under Population Pressure. London: G. Allen and Unwin.

Briggs, J, Badir, M and Mekki, A M (1999), Indigenous knowledge and vegetation use among Bedouin in the eastern desert of Egypt. Applied Geography. 19, 87-103.

CBS (2003), Population Monograph of Nepal. Kathmandu: Central Bureau of Statistics.

Chaudhary, S L and Manandhar, R (1996), Extension of Soil Fertility and Plant Nutrition Management: DOA's Experience. National Workshop on Soil Fertility and Plant Nutrition Management. Soil Science Division, Nepal Agricultural Research Council (NARC), Nepal.

Devkota, F R and Pradhan, P K (2006), Urban agriculture in Tokha, Kathmandu: Potentials for Urban Food Security and Employment. Agricultural Developmental Journal. Ministry of Agriculture, Department of Agriculture, Directorate of Agricultural Training.

ECOSOC (2000), Sustainable Agriculture and Rural Development. Commission on Sustainable Development, United Nations Economic and Social Council, Eighth Session, 24 April - 5 May.

Pradhan, P K (2008), Urban agriculture as an approach to urban poverty alleviation in Nepal. In: Pradhan, P K, Wastl-Walter, D and Folmar, S (eds.), Public Policy and Local Development: Opportunities and Constraints. A Publication of International Geographical Union (IGU), Bern, Switzerland.

Pradhan, P K (2004), Population growth, migration and urbanization: environmental consequences in Kathmandu valley, Nepal. In: Unruh, J D, Krol, M S and Kliot, N (eds.), Environmental Change and its Implications for Population Migration. Kluwer Academic Publishers.

Rajbanshi, Ashok (2009), Sustainable livelihood pattern of marginal communities in a peri-urban area: A case of Bajrayogini Village, Kathmandu District. Kathmandu: A Dissertation Submitted to the Faculty of Humanities and Social Sciences of Tribhuvan University in Fulfillment of the Requirement for the Degree of Doctor of Philosophy in GEOGRAPHY.

Rappaport, R A (1967), Ecology, Meaning and Religion. Berkeley, California: North Atlantic Books.

Sapkota, $\mathrm{K}$ and Andersen, $\mathrm{P}$ (2004), Commercial horticulture farming and its effect on soil fertility: a case study from peri-urban agriculture in the Kathmandu Valley. In: Andersen, P, Tuladhar, J K Karki, K B and Maskey, S L (eds.), Micronutrients in South and South East Asia. ICIMOD/NARC/ UIB.

Sapkota, K (2003), Continuity and Change: Knowledge and Practice of Peri Urban Agriculture, $A$ case of Manahara Low-Lying (Phant) Area, Madhyapurthimi Municipality, Bhaktapur District, Nepal. Unpublished MPhil Thesis. Department of Geography, University of Bergen, Norway. 